http://jmscr.igmpublication.org/home/

ISSN (e)-2347-176x ISSN (p) 2455-0450

crossref DOI: https://dx.doi.org/10.18535/jmscr/v10i1.29

\title{
Uptake of Papanicolaou Smear Test and Human Papiloma Virus Vaccines among Clients in Family Planning Clinic in Port Harcourt, Nigeria
}

Authors

\author{
Bassey Goddy, Omoruyi Solace, Oranu Emmanuel*
}

Department of Obstetrics and Gynaecology, University of Port Harcourt Teaching Hospital, Port Harcourt *Corresponding Author

Oranu Emmanuel

\begin{abstract}
Background: Papanicolaou Smear test has been used to screen for pre-malignant lesions of the cervix and its application has reduced the incidence of cervical cancer by over $70 \%$ in the last five decades. Human Papillomavirus (HPV) is a known cause of cervical cancer. HPV vaccination is a primary prevention of cervical cancer.

Objective: To determine the uptake of Papanicolaou smear test and human Papillomavirus (HPV) vaccine among the clients of the family planning clinic of the University of Port Harcourt Teaching Hospital (UPTH), Port Harcourt.

Method: This was a prospective descriptive cross-sectional study conducted among 236 female clients of the family planning clinic in UPTH. Selected participants completed a self administered structured questionnaire capturing information on socio-demographic characteristics and uptake of Papanicoalaou smear test and HPV vaccine. The data were entered into a spread sheet and analysed with Microsoft excel 2017 statistical software. The level of significance was set at $p<0.05$.

Results: The mean age of the respondents in the study was $36.41 \pm 6.01$ with (148) $39.8 \%$ aged between 30-39 years and (174) $73.73 \%$ were multiparous. Forty four (18.64\%) participants had done a pap smear and only $2.54 \%$ had received the HPV vaccine. There was a significant relationship between the level of education of participants and knowledge of PAP smear.

Conclusion: The uptake of PAP smear and HPV vaccine were very low. Education will improve the knowledge and hence uptake of PAP smear and HPV vaccine.

Keywords: Uptake, Papanicolaou Smear, Human Papillomavirus Vaccine, Port Harcourt.
\end{abstract}

\section{Introduction}

Cervical cancer is one of the leading causes of cancer worldwide, but to a large extent it is a preventable disease, because a persistent infection with high risk oncogenic forms of Human Papilloma virus (HPV) has been shown as the aetiological agent of the disease and vaccines targeting these oncogenic forms have been used to significantly reduce the incidence of cervical cancer $^{[1-3]}$. Cervical cancer accounts for $12 \%$ of all cancers worldwide and has shown varying agestandardized incidence rates; with high incidence 
in the developing world like Nigeria where a study showed a 28.5 per 100,000 women incidence rate; this is mainly due to lack of effective gynaecological screening programs ${ }^{[4]}$. Papanicolaou smear (Pap smear) has been the center piece of cervical cancer screening for over six decades and the screening programs have greatly reduced the rates of cervical cancer by upto $70 \%$ in developed world over this period ${ }^{[5,6]}$.

Since HPV is implicated in $70 \%$ of squamous cell carcinoma of the cervix, the use of vaccines against HPV has been shown to effectively prevent cancer of the cervix especially when a screening program is considered alongside the vaccination of young women ${ }^{[7]}$. Cervarix and Gardasil are the two vaccines currently used as specific prevention of HPV infection ${ }^{[1,7]}$. Until the middle of 2015, 60 (31\%) of 194 countries around the world have included the HPV vaccine in their national immunization programme. With the exception of South Africa, Rwanda, Libya and a few African countries, Nigeria and many other African countries are yet to introduce or have no plan to introduce the vaccine in their national immunization program ${ }^{[8]}$.

In a lot of molecular biological and epidemiologic studies, a strong association between Human Papilloma Virus infections (particularly serotypes 16 and 18) and cervical cancer, which tend to occur more during the period of cervical epithelial metaplasia in sexually active adolescents has been established $^{[9]}$. Sexual behaviours like early sexual debut, multiple sexual partners, parity, smoking and low educational status has been shown to increase the risk of chronic HPV infection and the burden of cervical cancer ${ }^{[10.11]}$. In Nigeria risky sexual behaviours are common among young people with sexual debuts at age as low as 16 years and with the practice of multiple sexual partners putting them at risk $^{[12,13]}$ Also some hypothesis claim that the use of hormonal contraceptives may increase the risk for HPV infection and development of cervical cancer. It is has been reported that long term use of combined oral contraceptives is associated with increased risk of HPV prevalence, but hormonal contraceptive use is not an independent risk factor for either high risk HPV infection or high-grade cervical intra-epithelial neoplasia $(\mathrm{CIN})^{[14-17]}$. Findings also show that Human Immunodeficiency Virus (HIV) positive women are at higher risk of developing abnormal cervical cytology, when compared to HIV negative women $^{[18,19]}$,

Due to available evidence on the role of HPV screening in reduction of invasive disease and death due to cervical cancer, the Canadian Task Force on Preventive Health Care recommends routine cervical cancer screening for women from the age of 25 years $^{[20]}$.

Human Papilloma Virus is one of the most common sexually transmitted infection and since 2006, there has been universal recommendation for vaccination of females of ages 9 to 26 years, but despite many females being at risk of HPV infection the uptake of the vaccine has been moderate to low due to various barriers of vaccination like knowledge gaps, concern of vaccine's adverse effect, cost, not knowing where to access the vaccine and cultural belief ${ }^{[21-24]}$. Although the use of HPV vaccines and screening programs have shown good prospects in reducing the incidence of cervical cancer, Gardasil dissemination programs had been suspended in Andhra and Gujarat in India in 2010 mainly due to lack of information and this desire for information has not been limited to India only; this emphasizes on the importance of appropriate information on the uptake of the vaccines ${ }^{[7]}$.

The efficacy of Cervarix (bivalent vaccine against HPV 16 and 18) and Gardasil (tetravalent vaccine against HPV 6, 11, 16 and 18) against initial and persistent infection with HPV has been demonstrated from data gathered from several clinical trials, thus it is recommended to be administered to females aged 9 to 13 years or women who have not been infected by HPV, with schedules of $0,1,6$ months for cervarix and 0,2 and 6 months for Gardasil ${ }^{[25]}$. 
Also the Gardasil-9 vaccine like the tetravalent Gardasil was approved in 2014 by Food and Drug Administration (FDA) in the United States, for use in both males and females aged 9 through 26 years, providing a wider coverage that includes type $31,33,45,52$, and 58 strains of the HPV virus $^{[26]}$.

The general uptake of Pap smear screening and HPV vaccination varies from low to high depending on the population, being more in developed countries with HPV immunization programs and amongst people with good socioeconomic status and access to reproductive healthcare facilities ${ }^{[19,22,27]}$.

In Nigeria similar studies show that awareness about Pap smear is low, being 30.8\% among women attending a Nigerian tertiary health institution, while HPV vaccine awareness was found to be $25.3 \%$ among female nurses in a tertiary institution in Nigeria ${ }^{[2,28]}$. Lack of awareness, absence of standard screening protocol, absence of the vaccines in national immunization programs, high cost of vaccine and low health insurance coverage have been major factors for low uptake of cervical cancer screening and vaccination in Nigeria ${ }^{[29]}$.

\section{Method}

This was a hospital based cross sectional descriptive study among women attending the family planning clinic of the University of Port Harcourt Teaching Hospital from January to March 2020. The sample size was determined with the Leslie Kish' formula ${ }^{[30]}$ for single proportions which states: $n=z^{2} p q / d^{2}$. Where $\mathrm{n}=$ minimum sample size; $\mathrm{z}=$ standard normal deviate of 1.96 when the critical limit is set at 95\% confidence interval in a two-tailed hypothesis test; $\mathrm{p}=$ awareness of existence of HPV vaccine among women attending gynaecology outpatient clinic according to a similar study done in Lagos by Kehinde S. Okunade $^{[31]} ; \mathrm{d}=$ degree of accuracy desired or maximum allowable margin of error set at $5 \%$; and $\mathrm{q}=1-\mathrm{p}$. Hence $n=235.53$
Bearing 5\% attrition rate, data was collected from 248 participants. Using convenient sampling technique, a structured self administered questionnaire was done as clients present to the clinic. The data collected include sociodemographic characteristics; with the different categories of occupation modified from international standard classification of occupation $^{[32,33]}$. Also assessed were the risk factors for cervical cancer, knowledge and uptake of Papanicolou smear test and HPV vaccine among participants.

Statistical analysis of data was done using Chisquare test to compare categorical variable, and p-value $<0.05$ was considered significant. Results were presented as means with standard deviation, rates and proportions in tables and figures.

Ethical approval was granted by the ethics committee of the hospital and participants signed the consent page of the structured questionnaire before participating.

\section{Results}

Two hundred and thirty six properly completed questionnaires out of the two hundred and forty eight questionnaires filled were analyzed. The mean age of the respondents in the study was $36.41 \pm 6.01$ with $39.8 \%$ (148) aged between 3039 years; and $73.73 \%$ (174) were multiparous. The number of respondents residing in the urban region were 214 (90.68\%), 228 (96.61\%) were married, and 234 (99.15\%) were Christians. Most of them, $162(68.64 \%)$ had tertiary education. Table 1 shows the socio-demographic indices of the respondents.

The age at first sexual intercourse was less than 16 years in $78(33.05 \%)$ of the respondents. The number of participants who had more than one sexual partner was $104(44.07 \%)$, and only 2 $(0.85 \%)$ of the respondents admitted cigarette smoking. Table 2 shows the risk factors for cervical cancer among participants, while Figure 2 shows their pattern of contraceptive use.

One hundred and fifty six $(66.10 \%)$ of the respondents have heard of cervical cancer, 118 
$(50 \%)$ were aware of papanicolou smear, and forty four (18.64\%) had done a pap smear.

Only 106 (44.92\%) respondents think that women above 25 years should do a pap smear. Among the participants who had not done pap smear, 94 $(48.96 \%)$ had not done it because they had no knowledge of the test.

A reasonable number of the participants, 204 (86.44\%) agreed to do a pap smear if the test is explained to them. Of the respondents who said they will not do the test even if it is explained to them, cost was the main issue. Table 3 shows the respondents knowledge and uptake of cervical cancer and Papanicolou smear test. Figure 3 shows the source of information about Pap smear. Sixty $(25.42 \%)$ of the participants have heard of Human Papilloma Virus and $40(16.95 \%)$ said it is sexually transmitted. Also only 40 (16.95\%) participants have heard of the HPV vaccine. Table 4 shows the distribution of participant's knowledge of HPV and HPV vaccine, while Figure 4 shows the distribution of the sources of knowledge of the vaccine.

Only 6 (2.54\%) respondents had vaccination against HPV. Among the 230 respondents who have not been vaccinated 137, (59.57\%) said it was because they didn't know about the vaccine. Thirty two of the respondents $(13.56 \%)$ said they will not take the vaccine even if they are enlightened and eligible. The distribution of uptake of the vaccine amongst respondents is shown on Table 5 and figure 5 shows the distribution of participants and reasons for not being vaccinated.

Table 1 Sociodemographic characteristics of participants

\begin{tabular}{|c|c|c|}
\hline Variable & Frequency $(\mathrm{N}=236)$ & Percentage $(\%)$ \\
\hline \multicolumn{3}{|l|}{ Distribution of Age (Years) } \\
\hline $20-29$ & 37 & 15.68 \\
\hline $30-39$ & 121 & 51.27 \\
\hline $40-49$ & 74 & 31.36 \\
\hline $50-59$ & 4 & 1.69 \\
\hline \multicolumn{3}{|l|}{ Distribution of Parity } \\
\hline Grandmultipara & 36 & 15.25 \\
\hline Multipara & 174 & 73.73 \\
\hline Primipara & 26 & 11.02 \\
\hline \multicolumn{3}{|l|}{ Type of Residence } \\
\hline Rural & 22 & 9.32 \\
\hline Urban & 214 & 90.68 \\
\hline \multicolumn{3}{|l|}{ Marital Status } \\
\hline Single & 8 & 3.39 \\
\hline Married & 228 & 96.61 \\
\hline \multicolumn{3}{|l|}{ Religion } \\
\hline Christianity & 234 & 99.15 \\
\hline Islam & 2 & 0.85 \\
\hline Highest completed Level of & & \\
\hline \multicolumn{3}{|l|}{ Education completed } \\
\hline None & 0 & 0.00 \\
\hline Primary & 4 & 1.69 \\
\hline Secondary & 70 & 29.66 \\
\hline Tertiary & 162 & 68.64 \\
\hline \multicolumn{3}{|l|}{ Occupation } \\
\hline Business & 18 & 7.63 \\
\hline Civil servant & 52 & 22.03 \\
\hline $\begin{array}{l}\text { Formally employed in private sector } \\
\text { e.g. banker }\end{array}$ & 50 & 21.19 \\
\hline Skilled Artisan & 42 & 17.80 \\
\hline House wife & 40 & 16.95 \\
\hline Unemployed & 34 & 14.41 \\
\hline
\end{tabular}


Table 2 Risk Factors for Cervical Cancer among Participants

\begin{tabular}{lcc} 
Variable & Frequency $(\mathbf{N}=\mathbf{2 4 6})$ & Percentage $(\%)$ \\
\hline Age at marriage & & \\
Less than 18 years & 50 & 21.19 \\
Greater than 18years & 178 & 75.42 \\
Not married & 8 & 3.39 \\
Age at First Sexual Intercourse & 78 & \\
Less than 16 years & 158 & 33.05 \\
Greater than 16 years & & 66.95 \\
Have you had more than one sexual & & \\
partner? & 132 & 55.93 \\
No & 104 & 44.07 \\
Yes & & \\
Do you smoke cigarette? & 234 & 99.15 \\
No & 2 & 0.85 \\
Yes & & \\
\hline
\end{tabular}

Table 3: Awareness and uptake of PAP smear

\begin{tabular}{|c|c|c|}
\hline Variable & Frequency $(\mathrm{N}=236)$ & Percentage $(\%)$ \\
\hline \multicolumn{3}{|l|}{ Have you heard of cervical cancer? } \\
\hline No & 80 & 33.90 \\
\hline Yes & 156 & 66.10 \\
\hline \multicolumn{3}{|l|}{$\begin{array}{l}\text { Have you heard of Pap smear screening for } \\
\text { Cervical Cancer? }\end{array}$} \\
\hline No & 118 & 50.00 \\
\hline Yes & 118 & 50.00 \\
\hline \multicolumn{3}{|l|}{$\begin{array}{l}\text { Do you think women above } 25 \text { years should } \\
\text { have pap smear? }\end{array}$} \\
\hline Yes & 106 & 44.92 \\
\hline No & 130 & 55.08 \\
\hline \multicolumn{3}{|l|}{$\begin{array}{l}\text { Have you done a Pap smear screening for } \\
\text { Cervical Cancer? }\end{array}$} \\
\hline Yes & 44 & 18.64 \\
\hline No & 192 & 81.36 \\
\hline \multicolumn{3}{|l|}{$\begin{array}{l}\text { If you have done a Pap smear, how many } \\
\text { times? }\end{array}$} \\
\hline Three or more & 6 & 13.64 \\
\hline Twice & 6 & 13.64 \\
\hline Once & 32 & 72.73 \\
\hline Total & 44 & 100.00 \\
\hline \multicolumn{3}{|l|}{ Reasons for not doing Pap smear } \\
\hline $\begin{array}{l}\text { No prior access to health facility providing pap } \\
\text { smear service. }\end{array}$ & 5 & 2.60 \\
\hline No medical Advice & 46 & 23.96 \\
\hline Cost & 47 & 24.48 \\
\hline No Knowledge & 94 & 48.96 \\
\hline Total & 192 & 100.00 \\
\hline \multicolumn{3}{|l|}{ How often should you do a Pap smear? } \\
\hline Every 6 months & 24 & 10.17 \\
\hline Yearly & 10 & 4.24 \\
\hline Every 3 years & 34 & 14.41 \\
\hline No idea & 168 & 71.19 \\
\hline \multicolumn{3}{|l|}{$\begin{array}{l}\text { If pap smear screening is well explained to } \\
\text { you, will you consider doing the test? }\end{array}$} \\
\hline No & 32 & 13.56 \\
\hline Yes & 204 & 86.44 \\
\hline \multicolumn{3}{|l|}{$\begin{array}{l}\text { If you will not do Pap smear, after being } \\
\text { educated why? }\end{array}$} \\
\hline I won't get the disease & 8 & 25.00 \\
\hline Personal belief & 10 & 31.25 \\
\hline Cost (it's expensive) & 14 & 43.75 \\
\hline
\end{tabular}


Figure 1

\section{Sources of knowledge about PAP smear}

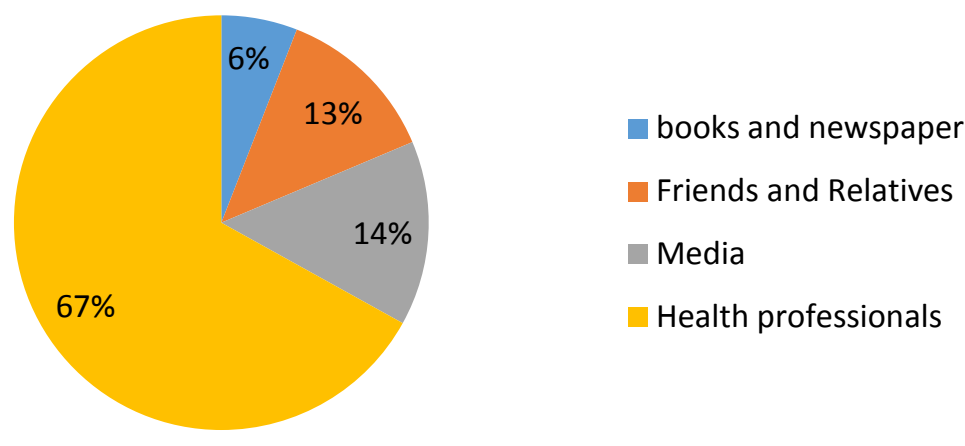

Table 4 Knowledge of Human Papilloma Virus and Vaccine

\begin{tabular}{lcc} 
Variable & Frequency (N=236) & Percentage (\%) \\
\hline Have you heard of Human Papilloma & & \\
Virus? & 60 & 25.42 \\
Yes & 176 & 74.58 \\
No & & \\
Is HPV sexually transmitted? & 36 & 15.25 \\
No & 40 & 16.95 \\
Yes & 160 & 67.80 \\
I don't know & & \\
Can HPV Cause Cervical Cancer? & 30 & 12.71 \\
No & 38 & 16.10 \\
Yes & 168 & 71.19 \\
Idon't know & & \\
Have you heard of HPV Vaccine? & 40 & 16.95 \\
Yes & 196 & 83.05 \\
No & & \\
Can HPV Vaccine Prevent cervical & & \\
cancer? & 26 & 11.02 \\
No & 36 & 15.25 \\
Yes & 174 & 73.73 \\
I don't Know & & \\
Do you know where you can get HPV & & \\
vaccine? & & 13.56 \\
Yes & 32 & 86.44 \\
No & 204 & \\
\hline
\end{tabular}

Figure 2

\section{Sources of Knowledge about HPV and HPV Vaccine}

$\square$ Family and Friends $\square$ Books/Newspapers $\square$ Media $\square$ Health Professionals

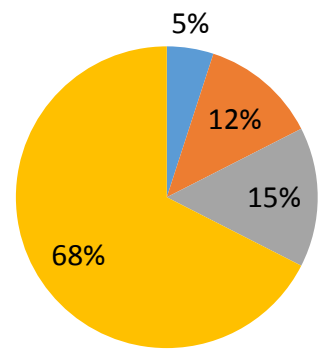


Table 5: Uptake of HPV Vaccine

\begin{tabular}{lcc} 
Variable & Frequency $(\mathbf{N}=\mathbf{2 3 6})$ & Percentage $(\%)$ \\
\hline Have you been Vaccinated against & & \\
HPV? & 6 & 2.54 \\
Yes & 230 & 97.46 \\
No & & \\
If you are enlightened and eligible & & \\
for the vaccine, will you get & 32 & 13.56 \\
vaccinated? & 204 & 86.44 \\
No & & \\
Yes & & \\
If you will not take the vaccine, & 6 & 18.75 \\
why? & 9 & 28.13 \\
Cost (it's expensive) & 17 & 53.13 \\
I won't get the disease & & \\
Personal belief &
\end{tabular}

Figure 3

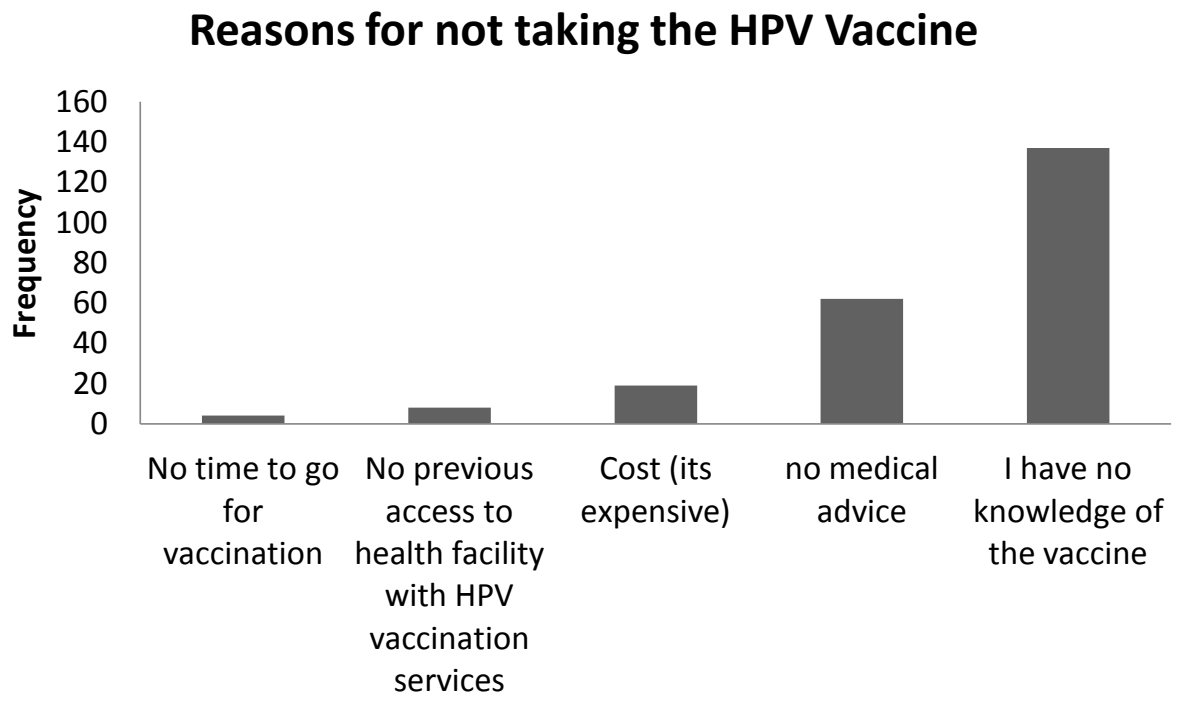

A statistical analysis was performed to find relationship between levels of education and participant's awareness of PAP smear test and relationships was determined by using Pearson's Chi-square test of independence. The results are shown in tables 6 and 7 below.

HPV vaccine. The significance of these

Table 6. Relationship between level of education and awareness of PAP smear screening test among participants

\begin{tabular}{|c|c|c|c|c|c|}
\hline \multirow[t]{2}{*}{ Variables } & \multicolumn{5}{|c|}{ Have you heard of PAP smear screening? } \\
\hline & $\begin{array}{c}\text { Yes } \\
N=118 \\
n(\%)\end{array}$ & $\begin{array}{c}\text { No } \\
N=118 \\
n(\%)\end{array}$ & $\begin{array}{c}\text { Total } \\
N=236 \\
n(\%)\end{array}$ & $\square^{2}$ & $P$ \\
\hline $\begin{array}{l}\text { Highest Level of } \\
\text { Education } \\
\text { attained. }\end{array}$ & & & & & \\
\hline Primary & $0(0.0)$ & $4(100.0)$ & $4(1.7)$ & & \\
\hline Secondary & $18(25.7)$ & $52(74.3)$ & $70(29.7)$ & & \\
\hline Tertiary & $100(61.7)$ & $62(38.3)$ & $162(68.6)$ & 27428 & $* 0000001107$ \\
\hline
\end{tabular}

$*$ Statistically significant at $\mathrm{p}<0.05$ 
Table 7: Relationship between level of education and awareness of HPV vaccine among participants

\begin{tabular}{|c|c|c|c|c|c|}
\hline Variables & $\begin{array}{c}\text { Have you ever heard of } \\
\text { HPV vaccine? }\end{array}$ & & & & \\
\hline & $\begin{array}{c}\text { Yes } \\
N=40 \\
n(\%)\end{array}$ & $\begin{array}{c}\text { No } \\
N=196 \\
n(\%)\end{array}$ & $\begin{array}{c}\text { Total } \\
N=236 \\
n(\%)\end{array}$ & $\square^{2}$ & $P$ \\
\hline $\begin{array}{l}\text { Highest Level of } \\
\text { Education attained. } \\
\text { Primary }\end{array}$ & $0(0.0)$ & $4(100.0)$ & $4(1.7)$ & & \\
\hline Secondary & $10(14.3)$ & $60(85.7)$ & $70(29.7)$ & & \\
\hline Tertiary & $30(18.5)$ & $132(81.5)$ & $162(68.6)$ & 0775 & 0678805 \\
\hline
\end{tabular}

Similar test above did not show any significant relationship between the level of education of participants and their awareness of HPV vaccine.

\section{Discussion}

The use of cervical cancer screening methods especially papanicolou smear and vaccination against Human Papilloma Virus has been shown to be strong preventive measures for cervical cancer among women in many countries ${ }^{[4,23,31]}$. The knowledge of cervical cancer, the screening and vaccination is critical to the uptake of these preventive measures in a community with identifiable risk factors. This study was carried out in a unit that offers reproductive health care service with information on diseases affecting the female reproductive health easily disseminated. In this study, the awareness of cervical cancer was above average; the proportion $(66.10 \%)$ was higher than that found in women dwelling in an urban slum in Lagos, Nigeria but similar to that in a hospital based study in Ethiopia ${ }^{[4,31]}$. However the knowledge of Human Papilloma Virus and mode of transmission of HPV was lower; but this fraction $(25.42 \%, 16.95 \%)$ was better than the study done among undergraduates in Lagos where $97 \%$ had poor knowledge of the virus ${ }^{[27]}$.

The awareness of Papanicolaou smear test and HPV vaccine were $50.00 \%$ and $15.25 \%$ respectively. The level of education had a significant effect on the knowledge of participants on Papanicolaou smear test but did not affect the knowledge of HPV vaccine. This effect of educational status on knowledge of cervical cancer and screening was similar to that found in a hospital based study in Ethiopia[34]. Even though the study population was mainly urban in this study, the knowledge of the participants on PAP smear was higher than what was found in a study in a North Western Nigerian tertiary institution like ours ${ }^{[35]}$. However the awareness for HPV vaccine was low and similar to a high level of lack of awareness of the vaccines among women in an urban community in Lagos Nigeria ${ }^{[36]}$. Also in this study $71.19 \%$ of the respondents had no idea of the correct basic knowledge of how often a PAP smear should be done.

The uptake of PAP smear test in this study was poor $(18.64 \%)$ and was similar to an uptake of $19.10 \%$ found among women attending a tertiary hospital in North western Nigeria ${ }^{[35]}$. This similarity could be attributed to the similarity of population of patients in a tertiary institution, as these levels of uptake were higher than what was found in a different non-hospital urban neighbourhood in Lagos ${ }^{[37]}$. Of all the participants in this study that had done a PAP smear most have done it only once, even though the average age of respondents was $36.41 \pm 6.01 \mathrm{SD}$. This study also identified various reasons respondents did not do PAP smear to include lack of knowledge (48.96\%), cost (24.48\%), no medical advice $(23.96 \%)$ and no previous access to health facilities carrying out PAP smear (2.60\%), which was similar to reasons found in another similar study in northern Nigeria ${ }^{[35]}$. However the willingness to do a PAP smear was high among respondents $(86.44 \%)$, while those who said they would not do the test gave reasons like cost, personal beliefs and firm belief that they will not 
get the disease, this was also found in similar studies $^{[9,34,37]}$.

The participants showed a very poor basic knowledge of the possibility of HPV causing cervical cancer, as $71.19 \%$ had no idea it could cause cervical cancer.

The uptake of the HPV vaccine was abysmally low in this study; the proportion $2.54 \%$ was similar to $2.60 \%$ uptake which was observed in a study among female undergraduates in Lagos ${ }^{[27]}$. However $13.56 \%$ of participants said they know where they can get vaccinated. The most common factors for non utilization of the vaccine was lack of knowledge amongst participants, no medical advice, cost, no access to health facility and lack of time to go and get vaccinated. Similar varying factors were noticed in the above study in Lagos $^{[27]}$. Another reason for the low uptake found in this study could be due to lack of government organized program on HPV vaccination. Contrarily, similar studies in developed countries like United States and Germany reported comparatively higher uptake of HPV vaccines of $62.4 \%$ and $53 \%$ respectively ${ }^{[38,39]}$. Most participants would get vaccinated with proper education while $13.56 \%$ will still not take the vaccine because of cost, personal belief and because they feel they will not get the disease. Generally, most studies reported that most common barriers to uptake of HPV vaccination were mostly due to insufficient information and high cost of the vaccine $^{[23,27,29,31,38,39]}$. Overcoming these barriers should be the target of interventions by increasing knowledge of HPV vaccine among young persons and also females of reproductive age with possible vaccination subsidization in Nigeria.

\section{Conclusion}

Although the awareness of PAP smear was average, that of HPV vaccine was significantly low. The uptake of PAP smear test and HPV vaccines were equally low. This was attributed mainly to the poor knowledge/awareness of PAP smear and HPV vaccine.

\section{Recommendation}

These findings highlight the need to use the human resources at the outlets of the reproductive health care services to provide educational/ sensitisation interventions. Also there is need for government's intervention initiatives to help improve awareness, reduce cost and improve access to these effective preventive measures of screening and vaccination for cervical cancer.

Consent: All the respondents in this study gave written informed consent.

Competing Intrest: authors declare that there is no competing interest among them.

\section{References}

1. World Health Organization (WHO). Comprehensive Cervical Cancer Control: A guide to essential practice. WHO Library Cataloguing-in-Publication Data. 2014.

2. Michael J. Campion KC. Cervical Cancer Screening and Preinvasive Disease. In: Jonathan S. Berek NFH, editor. Bereck \& Hacker's Gynaecologic Oncology. 6th ed. Wolters Kluwer; 2015. 242-325.

3. Nyengidiki TK, Oranu EO. Pattern of Cervical Cytology and High Risk Human Papillomavirus Strains in Non HIV Positive Women Presenting for Cervical Cancer Screening in Port Harcourt , Nigeria. J Biosci Med. 2018;6(6):68-76.

4. Balogun MR, Odukoya OO, Oyediran MA, Ujomu PI. Cervical cancer awareness and preventive practices: a challenge for female urban slum dwellers in Lagos, Nigeria. Afr J Reprod Health [Internet]. 2012;16(1):75-82. Available from: http://www.ncbi.nlm.nih.gov/pubmed/227 83671

5. Karjane NW, Ivey SE. Pap Smear: Overview, Indications, Preparation [Internet]. Medscape. 2016. Available from:

https://emedicine.medscape.com/article/19 
47979-overview

6. Schiffman M, Wentzensen N, Wacholder S, Kinney W, Gage JC, Castle PE. Human papillomavirus testing in the prevention of cervical cancer. J Natl Cancer Inst. 2011;103(5):368-83.

7. Harper DM, Williams KB. Prophylactic HPV vaccines: current knowledge of impact on gynecologic premalignancies. Discov Med [Internet]. 2010;10(50):7-17. Available from: https://emedicine.medscape.com/article/19 47979-overview

8. WHO. Vaccine in National Immunization Programme Update [Internet]. WHO; 2015. Available from: http://origin.who.int/immunization/monito ring_surveillance/VaccineIntroStatus_Mar ch2015.pptx

9. Biobaku O, Adesegun O Fatusi P. Perception, sources of information and utilization of papanicolaou (PAP) smear for cervical cancer screening among female nurses in Southwest Nigeria. Part 1. J Prev Infect Control. 2016;1(1):1-8.

10. Louie KS, De Sanjose S, Diaz M, Castellsagué X, Herrero R, Meijer CJ, et al. Early age at first sexual intercourse and early pregnancy are risk factors for cervical cancer in developing countries. $\mathrm{Br}$ J Cancer. 2009;100(7):1191-7.

11. Ononogbu U, Almujtaba M, Modibbo F, Lawal I, Offiong R, Olaniyan $\mathrm{O}$, et al. Cervical cancer risk factors among HIVinfected Nigerian women. BMC Public Health. 2013;13:582.

12. Imaledo JA, Peter-Kio OB, Asuquo EO. Pattern of risky sexual behavior and associated factors among undergraduate students of the university of port harcourt, rivers state, Nigeria. Pan Afr Med J. 2012;12(1):97.

13. Abiodun OM, Balogun OR. Sexual activity and contraceptive use among young female students of tertiary educational institutions in Ilorin, Nigeria. Contraception. 2009;79(2):146-9.

14. Marks M, Gravitt PE, Gupta SB, Liaw KL, Tadesse A, Kim E, et al. Combined oral contraceptive use increases HPV persistence but not new HPV detection in a cohort of women from Thailand. J Infect Dis. 2011;204(10):1505-13.

15. Marks M, Gravitt PE, Gupta SB, Liaw KL, Kim E, Tadesse A, et al. The association of hormonal contraceptive use and HPV prevalence. Int J Cancer. 2011;128(12):2962-70.

16. Gavrić-Lovrec V, Takač I. Use of various contraceptives and human papillomavirus 16 and 18 infections in women with cervical intraepithelial neoplasia. Int $\mathbf{J}$ STD AIDS. 2010;21(6):424-7.

17. Longatto-Filho A, Hammes LS, Sarian LO, Roteli-Martins C, Derchain SFM, Eren $\mathrm{M}$, et al. Hormonal contraceptives and the length of their use are not independent risk factors for high-risk HPV infections or high-grade CIN. Gynecol Obstet Invest. 2011;71(2):93-103.

18. Bassey G, Jeremiah I, Ikimalo JI, Fiebai PO, Athanasius BP. Abnormal cervical cytology among HIV-positive women in Nigeria. Int $\mathbf{J}$ Gynecol Obstet. 2014;125(2014):103-6.

19. Nyengidiki TK, Bassey G, Sapira-Odu L, Inimgba N, Athanasius B, Orazulike NC. Cervical Cytology or Colposcopy in the Identification of Cervical Intraepithelial Neoplastic Changes in Human Immunodeficiency Virus Positive Patients in an African Population? Indian J Gynecol Oncol [Internet]. 2017;15(2). Available from: https://doi.org/10.1007/s40944-017-01144

20. Dollin J. Preventing cervical cancer: Beyond following guidelines. Cmaj. 2013;185(1):13-4.

21. Holman DM, Benard V, Roland KB, 
Watson M, Liddon N, Stokley S. Barriers to human papillomavirus vaccination among us adolescents a systematic review of the literature. JAMA Pediatr. 2014;168(1):76-82.

22. Brewer NT, Fazekas KI. Predictors of HPV vaccine acceptability: A theoryinformed, systematic review. Prev Med (Baltim). 2007;45(2-3):107-14.

23. Makwe CC, Anorlu RI. Knowledge of and attitude toward human papillomavirus infection and vaccines among female nurses at a tertiary hospital in Nigeria. Int $\mathbf{J}$ Womens Health. 2011;3(1):313-7.

24. Caskey R, Lindau ST, Alexander GC. Knowledge and Early Adoption of the HPV Vaccine Among Girls and Young Women: Results of a National Survey. J Adolesc Heal. 2009;45(5):453-62.

25. World Health Organization. HPV Vaccination Comprehensive Cervical Cancer Draft. In: World Health Organization (2013) Chapter 4: HPV Vaccination Comprehensive Cervical Cancer Draft, 1-30 Retrieved from http://www.who.int/immunization/hpv/pla n/hpv_vaccine_intro_guide_c4gep_who_2 013.pdf [Internet]. 2013. p. 1-30. Available from: http://www.who.int/immunization/hpv/pla n/hpv_vaccine_intro_guide_c4gep_who_2 013.pdf

26. Petrosky E, Bocchini JA, Hariri S, Chesson H, Curtis CR, Saraiya M, et al. Use of 9-valent human papillomavirus (HPV) vaccine: updated HPV vaccination recommendations of the advisory committee on immunization practices. MMWR Morb Mortal Wkly Rep. 2015;64(11):300-4.

27. Oluwole E, Idowu O, Adejimi A, Balogun M, Osanyin G. Knowledge, attitude and uptake of human papillomavirus vaccination among female undergraduates in Lagos State, Nigeria. J Fam Med Prim
Care. 2019;8(11):3627-3633.

28. Shuaibu A, Grema B, Michael G. Pap smear awareness, utilization, and pattern of cervical intraepithelial neoplasia among women attending a tertiary hospital in Northwestern Nigeria. Muller J Med Sci Res. 2018;90-7.

29. Brown B, Folayan M. Barriers to uptake of human papilloma virus vaccine in Nigeria: A population in need. Niger Med $J$. 2016;56(4):301.

30. Singh AS, Masuku MB. Sampling Techniques \& Determination of Sample Size in Applied Statistics Research: An Overview. Int $\mathrm{J}$ Econ Commer Manag. 2014;2(11):1-22.

31. Okunade KS, Sunmonu O, Osanyin GE, Oluwole AA. Knowledge and Acceptability of Human Papillomavirus Vaccination among Women Attending the Gynaecological Outpatient Clinics of a University Teaching Hospital in Lagos, Nigeria. J Trop Med. 2017;2017(Article ID 8586459): 1-6.

32. Daniels R. International Standard Classification of Occupations. J Occup Environ Med. 1959;1(11):615.

33. Connelly R, Gayle V, Lambert PS. A Review of occupation-based social classifications for social survey research. Methodol Innov. 2016;9:205979911663800.

34. Tekle T, Wolka E, Nega B, Kumma WP, Koyira MM. Knowledge, attitude and practice towards cervical cancer screening among women and associated factors in hospitals of Wolaita zone, southern Ethiopia. Cancer Manag Res. 2020;12:993-1005.

35. Shuaibu A, Grema B, Michael G. Pap smear awareness, utilization, and pattern of cervical intraepithelial neoplasia among women attending a tertiary hospital in Northwestern Nigeria. Muller J Med Sci Res. 2018;9(2):90-7. 
36. Ezenwa BN, Balogun MR, Okafor IP. Mothers' human papilloma virus knowledge and willingness to vaccinate their adolescent daughters in Lagos, Nigeria. Int $\mathbf{J}$ Womens Health. 2013;5(1):371-7.

37. Wright KO, Aiyedehin O, Akinyinka MR, Ilozumba O. Cervical Cancer: Community Perception and Preventive Practices in an Urban Neighborhood of Lagos (Nigeria). ISRN Prev Med. 2014;2014:950534.

38. Schülein S, Taylor KJ, König J, Claus M, Blettner M, Klug SJ. Factors influencing uptake of HPV vaccination among girls in Germany. BMC Public Health [Internet]. 2016;16(1):1-8. Available from: http://dx.doi.org/10.1186/s12889-016$3663-\mathrm{z}$

39. Liu G, Kong L, Du P. HPV vaccine completion and dose adherence among commercially insured females aged 9 through 26 years in the US. Papillomavirus Res. 2016;2(2016):1-8. 